\title{
Do Individual Factors Affect the Relationship between Faculty Intrapreneurship and the Entrepreneurial Orientation of Their Organizations?
}

\author{
Ahmed Bani-Mustafa ${ }^{1, *}$, Sam Toglaw ${ }^{2}$, Oualid Abidi $^{3}(\mathbb{D}$ and Khalil Nimer 4 \\ 1 Mathematics and Physics Department, College of Engineering, Australian College of Kuwait, \\ Kuwait City 13015, Kuwait \\ 2 Department of Marketing, School of Business, Australian College of Kuwait, Kuwait City 13015, Kuwait; \\ s.toglaw@ack.edu.kw \\ 3 Department of Management, School of Business, Australian College of Kuwait, Kuwait City 13015, Kuwait; \\ o.abidi@ack.edu.kw \\ 4 Department of Accounting and MIS, School of Business, Gulf University for Science and Technology, \\ Mubarak Al-Abdullah 32093, Kuwait; ahmadnimer.k@gust.edu.kw \\ * Correspondence: a.mustafa@ack.edu.kw
}

Citation: Bani-Mustafa, Ahmed, Sam Toglaw, Oualid Abidi, and Khalil Nimer. 2021. Do Individual Factors Affect the Relationship between Faculty Intrapreneurship and the Entrepreneurial Orientation of Their Organizations? Economies 9: 199. https://doi.org/10.3390/economies 9040199

Academic Editors: João Carlos Correia Leitão and Dina Batista Pereira

Received: 12 November 2021 Accepted: 10 December 2021 Published: 16 December 2021

Publisher's Note: MDPI stays neutral with regard to jurisdictional claims in published maps and institutional affiliations.

Copyright: (c) 2021 by the authors. Licensee MDPI, Basel, Switzerland. This article is an open access article distributed under the terms and conditions of the Creative Commons Attribution (CC BY) license (https:// creativecommons.org/licenses/by/ $4.0 /)$.

\begin{abstract}
Several colleges and universities in the Middle East have been undertaking significant initiatives to forge and foster corporate entrepreneurship. The viability and success of those initiatives rest upon the input of faculty, possessing to various degrees an entrepreneurial orientation that revolves around innovativeness, risk-taking, and proactivity. This study investigates the extent to which individual-level factors moderate the influence of faculty entrepreneurial behavior on the entrepreneurial orientation of higher education institutions in Kuwait. These factors include gender, academic qualifications, teaching experience, school affiliation, scientific productivity, industrial experience, and professional certification. Data were collected using questionnaires filled by 291 faculty members, and the model was analyzed using structural equation modelling. The differences for each faculty characteristic in the structural path coefficients were tested using the Z-score statistics. The eight hypotheses that were partially validated as the most notable findings indicate that entrepreneurial orientation among male or business faculty has a greater impact on their institutions' organizational, entrepreneurial orientation. In contrast, the differences for the rest of the moderating characteristics were insignificant. The originality of this study pertains to the fact that the scope of faculty intrapreneurship does not seem to be strongly affected by any individual-level characteristic.
\end{abstract}

Keywords: faculty intrapreneurship; entrepreneurial orientation; faculty characteristics; structural equation modelling

\section{Introduction}

Corporate entrepreneurship reflects a strategy that organizations adopt to pursue innovation and expansion. Similarly, intrapreneurship represents an employee's willingness and engagement towards achieving their entrepreneurial vision (Amo 2010).

In recent years, corporate entrepreneurship gained significant attention from scholars (Boon et al. 2013; Woo 2018). It draws on the individual contributions of organizational members (Kearney 2013). It reflects the activities carried out by the employees in pursuit of organizational development and expansion (Hornsby et al. 2013). Kreiser et al. (2021) demonstrated that corporate entrepreneurship stems from the exhibition of an entrepreneurial strategic vision (or strategic intentionality), a pro-entrepreneurial organizational architecture, and a strong entrepreneurial orientation among the employees expressed in terms of innovativeness, proactiveness, and risk-taking. The internal fit between those three elements yields positive implications on the firm's financial performance. 
Indeed, the effectiveness of organizations depends to a large extent on how internal competencies are built and upgraded. Employees are micro actors who initiate change at the macro-organizational level as they undertake intrapreneurial activities based on practice and learning (Kim 2012). Organizational members participate in activities that enable them to access and accumulate value-adding resources (Hobfoll 2001). In their systematic review, Wahyudi et al. (2021) portrayed entrepreneurial orientation as one of the core aspects of corporate entrepreneurship along with other constituents, i.e., entrepreneurial management, entrepreneurial leadership, and performance.

Evidence shows that employee intrapreneurship contributes to gaining personal resources and increases work engagement (Gawke et al. 2017). Moreover, it was argued that employee intrapreneurship is the source of several organizational outcomes, namely innovation capacity, market growth, and financial performance (Bierwerth et al. 2015). Promoting employee intrapreneurship is rewarding to organizations in terms of innovation and adaptivity to the organizational environment. Effective organizations encourage their staff to engage in voluntary information manipulation and to foster innovative mindsets (Park et al. 2014), notably through effective and spiritual leadership (Farrukh et al. 2021; Usman et al. 2021).

Intrapreneurship at the individual level designates the activities characterized by initiation, risk-taking, and ideation (de Jong et al. 2015). However, in this study, we will explore the implications of faculty intrapreneurship at the organization's level and examine how the entrepreneurial orientation of faculties could support the entrepreneurial orientation of the higher education institutions (HEI) in Kuwait. The majority of previous studies conducted on academic entrepreneurship have mainly observed the implications pertaining to the university business venturing, i.e., university spin-offs (Audretsch 2014; Cvijić et al. 2019; Fini et al. 2017). In fact, this is an instance of corporate entrepreneurship driven by the organization's entrepreneurial orientation, i.e., strategy-making processes aiming to enhance the organizational purpose and develop competitive advantages (Bakar and Mahmood 2014; Rauch et al. 2009). A firm's entrepreneurial orientation encompasses innovativeness, risk-taking, and proactiveness (Covin and Slevin 1989).

The present research aims to investigate the extent to which individual characteristics moderate the relationship between the entrepreneurial orientation of the academic staff and the entrepreneurial orientation of their HEIs. More specifically, this study will examine the moderating effects of gender, qualifications (Ph.D. Masters), teaching experience, affiliation (business; engineering), scientific productivity, professional experience, and professional certifications. There is no empirical evidence that describes the internal processes supporting corporate entrepreneurship in academic settings, essentially those pertaining to the engagement of academic staff. Only one recent study indicates that intrapreneurial behavior among academic and non-academic personnel in Latvian universities is correlated with an employee's initiative but with no association with neither risk-taking nor personal initiative (Valka et al. 2020). Therefore, this research will address this gap by suggesting and validating a framework that highlights the individual and organizational dynamics of entrepreneurial orientation at Kuwaiti HEIs and their relationship.

\section{Theoretical Background}

The literature largely depicted intrapreneurship as an antecedent of corporate performance (Burgelman 1983). The pro-entrepreneurship cognitions of either managerial or non-managerial staff in the form of beliefs, attitudes, and values that are non-context specific and are likely to strengthen corporate entrepreneurship at the firm's level (Ireland et al. 2009). A recent study proved that employee engagement positively mediates the relationship between corporate entrepreneurship and business performance (Ahmed et al. 2020). As a construct, intrapreneurship is defined as "the process by which teams within an established company conceive, foster, launch and manage a new business that is distinct from the parent company but leverages the parent's assets, market position, capabilities or other resources" (Wolcott and Lippitz 2007). 
Employee behavioural factors (i.e., subjective norms, attitude towards intrapreneurship, and perceived behavioural control) and how they perceive the entrepreneurial orientation of their organization positively influence the strategic renewal behaviour and venture behaviour (Do and Luu 2020). Indeed, individual intrapreneurship identifies and exploits market opportunities that allow the organization to reinvent its offerings and strengthen its competitiveness (Neessen et al. 2019). Employees' entrepreneurial activities flourish when they operate in an organic and flexible organizational structure (Nielsen et al. 2019). Previous studies show that employee intrapreneurship is influenced by a myriad of factors such as managerial support (Lizote et al. 2014; ul Haq et al. 2018), engaging leadership (Nielsen et al. 2019), job design (Mustafa et al. 2018), and organizational justice (ul Haq et al. 2018).

Ahmed et al. (2020) posit that employees' engagement and their contribution to the business performance will be enhanced when an organization provides proper treatment to employees through management support, sufficient time to accomplish the work duties, the autonomy to work at the manager's own discretion, clear organizational boundaries, and a reward system for creativity and innovation.

Gawke et al. (2017) identify two types of behaviour that derive from employee intrapreneurial activities, i.e., new business venturing and strategic business renewal. While new business venturing refers to firms' expansion into new product markets, strategic business renewal focuses on enhancing organizational competitiveness and its capacity to cope with internal and external changes (Gawke et al. 2017, 2019; Yang et al. 2009). Strategic business renewal also encompasses adapting the organizational structure, optimizing resource allocations, and revitalizing product and service offerings (Ireland et al. 2003).

HEIs could be recognized as organizational environments wherein corporate entrepreneurship is taking place. Indeed, they draw upon a competence-based approach supported by a dynamic of knowledge creation and sharing between the academic personnel (Bratianu et al. 2020). In today's competitive educational environment, faculties are expected to adopt an entrepreneurial orientation that revolves around innovativeness, risk-taking, and proactivity (Hayat 2011). This idea is consistent with the view of organizational members as precursors of corporate entrepreneurship through the individual and collective actions and risk-taking behaviours that they undertake (Kearney 2013). Such actions and behaviours could be recognized as reflecting individual intrapreneurship in an HEI setting. Faculties have a prominent role in nurturing the entrepreneurial orientation of those HEIs through their industry links, engagement in different committees, and close collaborations with the management and the administrative staff (Clark 2004).

In addition, academics' contributions occur through another area of HEI corporate entrepreneurship, namely students' engagement and service to the community. Faculties act as mentors to students who undertake initiatives for the sake of local communities and organizations (Davis and Jacobsen 2014). Faculties can also support the competitiveness of their institutions and their impact within local communities when they incorporate the latest innovations and technological tools into their academic activities to make the business competitive (Meilani and Ginting 2018).

Another area that requires faculty intrapreneurship is university spin-offs (spin-outs in the British dictionary). A company is founded to exploit the results of university research, and the university will invest in protecting its research intellectual property in return for getting shares in the company. Faculty members with intrapreneurial orientation are necessary to initiate contacts with the industry, identify potential clients, provide demonstrations that present the value of their research output or inventions, and take active roles in forming the spin-off to commercialize research output. University spin-offs (USOs) play an important role in maintaining sustainability, enhancing their local economic position, and assisting universities in their major mission of teaching and research (Shane 2004). As colleges and universities are in a constant development cycle in relation to updating their academic programs and expanding their offerings, they need to be proactive and innovative to recruit new students in a competitive environment. Intrapreneurial faculties 
take practical steps to benefit from Alumni and industry advice in developing current and new courses, initiating new minors and majors, and creating centres of excellence in various fields (Brooksbank and Thomas 2001).

\section{Hypotheses Development}

Figure 1 above illustrates the central assumption adopted in this study which stipulates that faculty intrapreneurship is a potential driver of significant changes in HEIs in different aspects. Consistent with a large body of scholarship (Ireland et al. 2009; Kreiser et al. 2021), the entrepreneurial behaviours exhibited by organizational members are key to corporate entrepreneurship. As stated in Hypothesis 1 hereunder, we expect to observe the same type of relationship in the context of higher educational institutions in Kuwait.

Hypothesis 1 (H1). Faculty Entrepreneurial Orientation (FEO) positively influences the Entrepreneurial Orientation of Higher Education Institutions in Kuwait (EOHEI).

Figure 1 also illustrates a possible moderating effect on the main relationship argued for in Hypothesis 1 and exerted by faculty characteristics such as gender, academic qualifications, and industry experience. Previous studies have indicated that gender and personal innovativeness influence faculty utilization of media tools and cutting-edge technologies (Aldahdouh et al. 2020). Another study proved that race and gender shape the attitude of academic staff towards the adoption of online education tools (Riggs 2019). Serinkan et al. (2013) demonstrated that female workers in the banking sector have a stronger entrepreneurial posture than their male counterparts. These assertions contradict the findings of Adachi and Hisada (2017), who found that, in general, women have a lesser inclination towards intrapreneurship than men. However, the study shows that women's intrapreneurial orientation is stronger when a small firm employs them. The present research does not establish any specific outcome expected as the literature provided a mitigated view about the gender effect.

Hypothesis 2 (H2). Gender moderates the relationship between Faculty Entrepreneurial Orientation (FEO) and the Entrepreneurial Orientation of Higher Education Institutions in Kuwait (EOHEI).

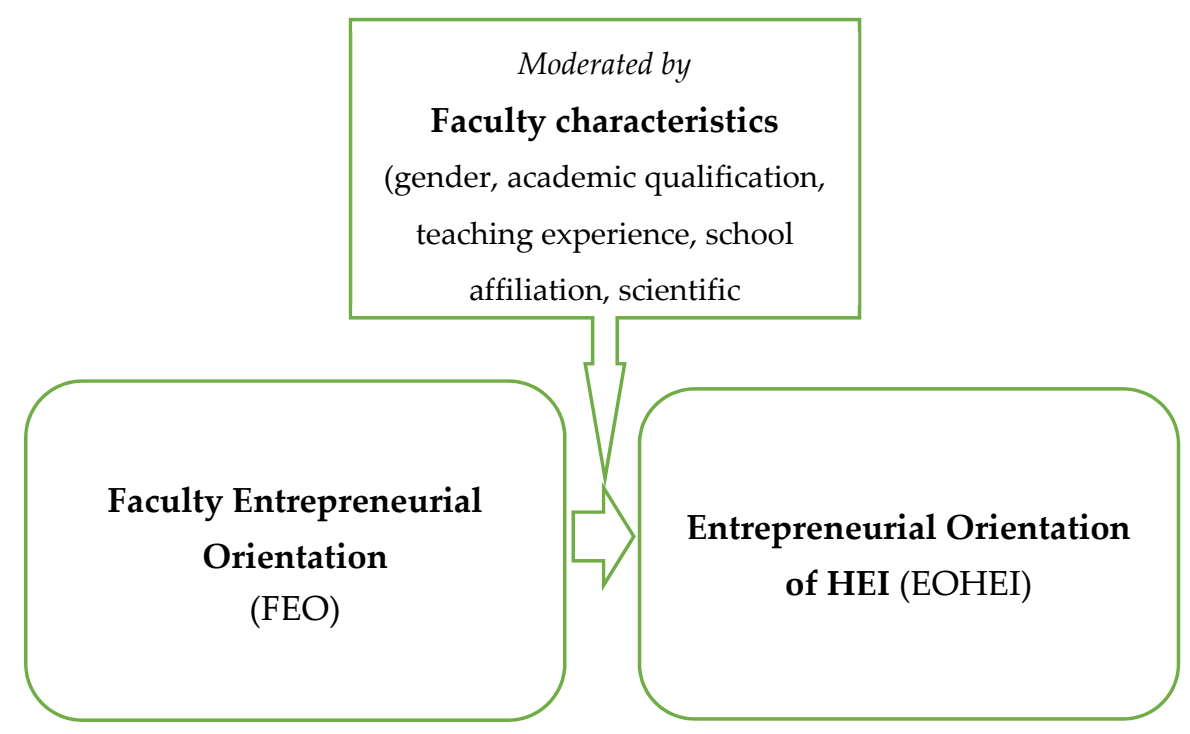

Figure 1. Conceptual Framework.

Similarly, the Martiarena (2013) study reveals that higher educational qualifications are typical of highly intrapreneurial employees. The possession of higher qualifications should be associated with more valuable contributions in fulfilling the growth plans of 
colleges and universities. Most faculty appointed to committees and top management positions in HEI in Kuwait are Ph.D. holders. Thus, they may be exerting a more significant role in the corporate entrepreneurship plans of their institutions than other faculty with lower qualifications.

Hypothesis 3 (H3). Academic Qualifications of a faculty member (Master's, Ph.D.) moderate the relationship between Faculty Entrepreneurial Orientation (FEO) and the Entrepreneurial Orientation of Higher Education Institutions in Kuwait (EOHEI).

Cumulating experience in teaching could allow faculty members to derive and test proposals that could be disseminated eventually in their HEIs as winning practices if proven to be valuable. Therefore, teaching experience is believed to play a positive moderation role in the relationship between FEO and HEIEO.

Hypothesis 4 (H4). Teaching Experience moderates the relationship between Faculty Entrepreneurial Orientation (FEO) and the Entrepreneurial Orientation of Higher Education Institutions in Kuwait (EOHEI).

As no evidence was traced in previous research, the study findings will determine the nature of the moderation effect relevant to faculty affiliation. However, the engineering faculty may have more potential to access, adapt and integrate a large array of technologies into their work. Hence, we would expect the effect of FEO on HEIEO to be stronger among engineering faculties.

Hypothesis 5 (H5). The School Affiliation (Business or Engineering) moderates the relationship between Faculty Entrepreneurial Orientation (FEO) and the Entrepreneurial Orientation of Higher Education Institutions in Kuwait (EOHEI).

Faculty specialization into their respective research streams is believed to develop their capacity to harness exceptional knowledge within their area of interest and reinforce their capacity to cooperate with key academia or industry stakeholders. As a result, scientific productivity is expected to increase the FEO effect on HEIEO.

Hypothesis 6 (H6). Scientific Productivity in terms of the number of publications in peer-reviewed journals moderates the relationship between Faculty Entrepreneurial Orientation (FEO) and the Entrepreneurial Orientation of Higher Education Institutions in Kuwait (EOHEI).

Furthermore, the amount of experience earned by a faculty in business consulting supports them in commercializing their scientific production (Hayter 2013). Additionally, the amount of training received supports an individual's capacity to identify opportunities when conducting explorative activities (Kraus et al. 2019). Overall, faculty exposure to the industry dynamics and the real issues organizations encounter could translate into effective teaching and research agendas executed under their HEI umbrella. Hence, the cumulation of a significant industry experience is supposed to positively moderate the causal effect of FEO on HEIEO. Consequently, the present study will test and validate the below hypothesis:

Hypothesis 7 (H7). Industrial Experience moderates the relationship between Faculty Entrepreneurial Orientation (FEO) and the Entrepreneurial Orientation of Higher Education Institutions in Kuwait (EOHEI).

Following the previous hypothesis (H7), earning professional certifications is another channel for faculties to increase their involvement as practitioners, whether locally or globally. The professional certifications offer valuable opportunities for faculties to expand 
their professional networks, which could be beneficial in supporting their academic duties and, ultimately, their contributions to the corporate entrepreneurship of their HEIs.

Hypothesis 8 (H8). Professional Certification moderates the relationship between Faculty Entrepreneurial Orientation (FEO) and the Entrepreneurial Orientation of Higher Education Institutions in Kuwait (EOHEI).

\section{Research Design}

An empirical investigation was conducted using primary data collected through questionnaires to test the research hypotheses. The questionnaire comprised three blocks, i.e., faculty characteristics, faculty entrepreneurial orientation, and entrepreneurial orientation of the organization (see questionnaire statements in Appendix A). Faculty members from the engineering and business colleges who work in HEIs in Kuwait were the target population. Choosing these two colleges is due to their existence in most Kuwaiti universities. The respondents were asked to rate each statement in the questionnaire on a 5-point Likert scale $(1=$ strongly disagree and $5=$ strongly agree $)$. Each construct was measured based on scales validated and used in previous studies.

\section{Sampling Frame, Instrument, and Data}

The questionnaire was sent to 341 faculty members who work in Kuwait private and public HEI across business and engineering schools. The total population is approximately 400 faculty members who are distributed over four engineering colleges (one in a public university and three in private universities) and six business colleges (one in a public university and five in private universities). The survey was sent to all faculties with an available and valid email address and was conducted from June to October 2020 using convenience sampling. By the end of October 2020, 291 usable responses were collected, representing a response rate of $85 \%$ and about $73 \%$ of the whole population. According to empirical standards, the sample size and response rates are acceptable (Cochran 1977). The descriptive statistics pertaining to the respondents are provided in Table 1 below:

Table 1. Distribution of the Sample. (Source: data collected through the questionnaire survey).

\begin{tabular}{|c|c|c|c|}
\hline Variable & Category & $\mathbf{n}$ & $\%$ \\
\hline \multirow{2}{*}{ Gender } & Male & 196 & 67.4 \\
\hline & Female & 95 & 32.6 \\
\hline \multirow{2}{*}{ Education Level } & Masters/MBA & 64 & 26.8 \\
\hline & $\mathrm{PhD}$ & 186 & 73.2 \\
\hline \multirow{3}{*}{ Age } & 25-34 years & 53 & 18.2 \\
\hline & $35-44$ years & 152 & 52.2 \\
\hline & $\geq 45$ & 86 & 29.6 \\
\hline \multirow{8}{*}{ Employer } & HEI 1 & 43 & 14.8 \\
\hline & HEI 2 & 42 & 14.4 \\
\hline & HEI 3 & 26 & 8.9 \\
\hline & HEI 4 & 28 & 9.6 \\
\hline & HEI 5 & 95 & 32.6 \\
\hline & HEI 6 & 34 & 11.7 \\
\hline & HEI 7 & 14 & 4.8 \\
\hline & HEI 8 & 9 & 3.1 \\
\hline
\end{tabular}


Table 1. Cont.

\begin{tabular}{|c|c|c|c|c|c|}
\hline Variable & \multicolumn{3}{|c|}{ Category } & $\mathbf{n}$ & $\%$ \\
\hline \multirow{2}{*}{ Academic Field } & \multicolumn{3}{|c|}{ Business } & 210 & 72.2 \\
\hline & \multicolumn{3}{|c|}{ Engineering } & 81 & 27.8 \\
\hline & \multicolumn{3}{|c|}{$0-1$} & 120 & 41.2 \\
\hline Number of & \multicolumn{3}{|c|}{$2-5$} & 128 & 43.9 \\
\hline Publications & \multicolumn{3}{|c|}{$6-10$} & 26 & 8.8 \\
\hline & \multicolumn{3}{|c|}{ More than 10} & 17 & 5.9 \\
\hline \multirow{5}{*}{ Management Style } & \multicolumn{3}{|c|}{ Authority-Compliance (efficiency)-1 } & 81 & 27.8 \\
\hline & \multicolumn{3}{|c|}{ Impoverished Management (laissez-faire management) - 2} & 38 & 13.1 \\
\hline & \multicolumn{3}{|c|}{ Country Club Management (friendly atmosphere)-3 } & 40 & 13.7 \\
\hline & \multicolumn{3}{|c|}{ Middle of the Road Management (balancing work and people)-4 } & 79 & 27.1 \\
\hline & \multicolumn{3}{|c|}{ Team Management (trust and respect) -5} & 53 & 18.2 \\
\hline \multicolumn{6}{|c|}{ Descriptive statistics } \\
\hline Teaching Experience & Mean $=12.6$ & Stdev $=6.2$ & $\operatorname{Min}=0$ & \multicolumn{2}{|c|}{$\operatorname{Max}=33$} \\
\hline Industrial Experience & Mean $=4.5$ & Stdev $=4.6$ & $\operatorname{Min}=0$ & \multicolumn{2}{|c|}{$\operatorname{Max}=25$} \\
\hline
\end{tabular}

\section{Analysis and Results}

Data were cleaned and analyzed using SPSS 24.0 and AMOS 25 software (SPSS Inc., Chicago, IL, USA). The research model was tested with maximum likelihood estimation using structural equation modelling (SEM). Such a method is recognized to be adequate for multiple regression modelling. SEM allows testing multi-equation regression models and multiple concepts measures that fit our research model. Additionally, the SEM method considers the correlations between the model variables.

\subsection{Exploratory Factor Analysis and Scale Reliability Analysis}

All items included in the survey were re-analyzed and validated with internal reliability values, Cronbach Alpha, and Bartlett's test (Hoque et al. 2018). The instruments used to capture Faculty Entrepreneurial Orientation (FEO) and Entrepreneurial Orientation of the higher education institution (EOHEI) were evaluated and validated based on 291 responses collected; 33 items were included in the survey, as shown in Table 2.

Table 2. Theoretical Background/Support for Scale Items, variables, and constructs.

\begin{tabular}{cc}
\hline Item Description & Theoretical Background \\
\hline Construct/variable: faculty entrepreneurial Orientation (FEO) \\
\hline Innovativeness-6 items & $\begin{array}{c}\text { Farrukh et al. (2017) -4 items } \\
\text { de Jong et al. (2015)—-2 items }\end{array}$ \\
Risk-taking-6 items & Farrukh et al. (2017) -3 items \\
de Jong et al. (2015)_items \\
Proactivity-3 items & de Jong et al. (2015) \\
\hline Risk-taking-3 items & Hughes and Morgan (2007) \\
Innovativeness-3 items & Hughes and Morgan (2007) \\
Proactiveness-3 items & Hughes and Morgan (2007) \\
Competitive aggressiveness—3 items & Hughes and Morgan (2007) \\
Autonomy-6 items & Hughes and Morgan (2007) \\
\hline
\end{tabular}

Sample adequacy for factor analysis was verified and proven to be significant at a $5 \%$ level based on Kaiser-Meyer-Oklin (KMO) and Bartlett's Sphericity with a chi-square value of $5867.888(\mathrm{df}=528)$.

The KMO statistic (0.864) exceeds the cut-off value of 0.50 (Hair et al. 2013). The results obtained by running factor analysis using Varimax rotation (Costello and Osborne 2005 ) resulted in cross-loadings $(>0.40)$ or communalities $(<0.30)$ (Hair et al. 2012), and 
eigenvalues more than one were taken as references. This analysis allowed the extraction of three factors, which explain a total variance of $66.7 \%$.

Further to conducting the internal reliability and exploratory factor analyses, only three items were discarded from the FEO construct, i.e., items 18, 23, and 30. Cronbach alpha values were also above the cut-off point of 0.7 for all variables and constructs with 0.73 for FEO and 0.845 for EOHEI.

\subsection{Measurement Model Estimation and Fit}

Before conducting the confirmatory factor analysis (CFA), the Kaiser-Meyer-Olkin (KMO) test was conducted to check the sampling adequacy. Bartlett's test of sphericity (Bartlett 1954) was also conducted to investigate the factorability of the data. Table 3 shows the suitability of the data for CFA and SEM, the KMO results of 0.813 (above 0.6 according to (Pallant 2013)), and a significant test statistic of sphericity at $0.1 \%$ level $(p<0.001)$.

Table 3. KMO and Bartlett's Test.

\begin{tabular}{lcc}
\hline \multicolumn{2}{c}{ Kaiser-Meyer-Olkin Measure of Sampling Adequacy. } & 0.813 \\
\hline \multirow{3}{*}{ Bartlett's Test of Sphericity } & Approx. Chi-Square & 1290.708 \\
\cline { 2 - 3 } & df & 105 \\
\cline { 2 - 3 } & Sig. & 0.000 \\
\hline
\end{tabular}

The confirmatory data analysis is conducted based on the proposed model confirming the number of constructs and the measured items loading. Using CFA to fit the results of our constructs, a Principal Components Analysis (PCA) with a Varimax Rotation was carried out, and the results are summarized in Table 4 . The total variance explained for the model ranged from 51.94 to $79.91 \%$, with a total of $64.74 \%$ for FEO and $66.5 \%$ for EOHEI. The factors with component values less than 0.4 were considered to have a weak correlation with the factor, and normally they are removed from the analysis. No items were removed from the analysis as they all meet the criteria as illustrated in Table 4 . The results also show that the sign of the items is the same, which indicates the measure fits the data well. Furthermore, all dimensions were above the recommended value of 0.7 (Moore and Benbasat 1991), ranging from 0.701 (proactivity) to 0.935 (Autonomy). The overall internal consistency estimate was 0.821 for FEO (12 items) and 0.92 for EOHEI.

Table 4. Percent of variance, Cronbach's Alpha, and component loading range.

\begin{tabular}{ccccc}
\hline Dimension & $\begin{array}{c}\text { Number of } \\
\text { Items }\end{array}$ & $\begin{array}{c}\text { Average Variance } \\
\text { Extracted (AVE) }\end{array}$ & $\begin{array}{c}\text { Cronbach's } \\
\text { Alpha }\end{array}$ & $\begin{array}{c}\text { Component } \\
\text { Loading Range }\end{array}$ \\
\hline FEO & $\mathbf{1 2}$ & $\mathbf{6 4 . 7 4}$ & $\mathbf{0 . 8 2 1}$ & \\
\hline Innovativeness & 6 & 51.94 & 0.777 & $0.621-0.766$ \\
Risk-Taking & 6 & 57.66 & 0.718 & $0.530-0.924$ \\
Proactivity & 3 & 57.67 & 0.701 & $0.718-0.800$ \\
\hline EOHEI & $\mathbf{1 8}$ & $\mathbf{6 6 . 5}$ & $\mathbf{0 . 9 2}$ & \\
\hline Autonomy & 6 & 79.91 & 0.935 & $0.734-0.933$ \\
Risk-taking & 3 & 72.06 & 0.805 & $0.667-0.785$ \\
Innovativeness & 3 & 72.02 & 0.803 & $0.786-0.883$ \\
Proactiveness & 3 & 75.01 & 0.833 & $0.826-0.906$ \\
Competitive & 3 & 67.75 & 0.753 & $0.780-0.869$ \\
aggressiveness & & & & \\
\hline
\end{tabular}

The measurement model was also used to validate the conceptual model (Moussa et al. 2020; Al-Momani et al. 2011; AlQudah et al. 2021), which argues for interrelationships between the two core constructs (FEO, EOHEI) and the moderating effect of faculty 
characteristics (gender, teaching experience, etc.) The results derived from the measurement model are shown in Table 5. FEO and EOHEI indicators and variables were highly significant at the alpha level of 0.001. As shown in Table 5, the goodness-of-fit (GOF) for all constructs were satisfactory based on the goodness-of-fit criteria (GFI, AGFI, CFI, and NFI $>0.90$ and RMSEA $<0.07$ ), suggesting that the hypothesized measurement model greatly fits the data. Overall, the measurement model results supported convergent, discriminant validities, and reliability of the measures used in the hypothetical study model.

Table 5. Statistics of Measurement Analysis (FEO and EOHEI).

\begin{tabular}{|c|c|c|c|c|c|}
\hline \multicolumn{2}{|c|}{ Constructs, Variables, and Items } & \multirow[t]{2}{*}{ Standardized Weights } & \multicolumn{2}{|c|}{ Goodness-of-Fit Indicators } & \multirow{2}{*}{$\begin{array}{c}\text { Accept. Standard Fit } \\
>0.90\end{array}$} \\
\hline FEO & Item & & GFI & 0.972 & \\
\hline \multirow{6}{*}{ Innovativeness } & Inn1 & $0.485^{* * *}$ & AGFI & 0.940 & $>0.90$ \\
\hline & Inn2 & $0.507^{* * *}$ & CFI & 0.986 & $>0.90$ \\
\hline & Inn3 & $0.381 * * *$ & NFI & 0.952 & $>0.90$ \\
\hline & Inn4 & $0.500^{* * *}$ & RMSEA & 0.036 & $<0.07$ \\
\hline & Inn5 & $0.680^{* * *}$ & & & \\
\hline & Inn6 & $0.648^{* * *}$ & & & \\
\hline \multirow{4}{*}{ Risk-Taking } & & $1.0 * * *$ & & & \\
\hline & RT1 & 0.306 & & & \\
\hline & RT2 & 0.304 & & & \\
\hline & RT3 & 0.354 & & & \\
\hline \multirow{4}{*}{ Proactivity } & & $1.0 * * *$ & & & \\
\hline & Pro1 & $0.722^{* * *}$ & & & \\
\hline & Pro2 & $0.520 * * *$ & & & \\
\hline & Pro3 & $0.557^{* * *}$ & & & \\
\hline \multicolumn{6}{|l|}{ EOHEI } \\
\hline \multirow{7}{*}{ Autonomy } & & $1.0^{* * *}$ & GFI & 0.971 & $>0.90$ \\
\hline & Auto1 & $0.514^{* * *}$ & AGFI & 0.923 & $>0.90$ \\
\hline & Auto2 & $0.515^{* * *}$ & CFI & 0.996 & $>0.90$ \\
\hline & Auto3 & $0.588^{* * *}$ & NFI & 0.980 & $>0.90$ \\
\hline & Auto4 & $0.538^{* * *}$ & RMSEA & 0.028 & $<0.07$ \\
\hline & Auto5 & $0.449^{* * *}$ & & & \\
\hline & Auto6 & $0.402^{* * *}$ & & & \\
\hline \multirow{7}{*}{ Risk-taking } & & $1.0 * * *$ & $1.0^{* * *}$ & $1.0^{* * *}$ & $1.0^{* * *}$ \\
\hline & & $0.439^{* * *}$ & $0.706^{* * *}$ & $0.702 * * *$ & $0.616^{* * *}$ \\
\hline & & $0.618^{* * *}$ & $0.769 * * *$ & $0.871^{* * *}$ & $0.362^{* * *}$ \\
\hline & & 0.633 & $0.818^{* * *}$ & $0.792 * * *$ & $0.501^{* * *}$ \\
\hline & RT1 & $0.439^{* * *}$ & & & \\
\hline & RT2 & $0.618^{* * *}$ & & & \\
\hline & RT3 & 0.633 & & & \\
\hline \multirow{4}{*}{ Innovativeness } & & $1.0^{* * *}$ & & & \\
\hline & Inn1 & $0.706^{* * *}$ & & & \\
\hline & Inn2 & $0.769^{* * *}$ & & & \\
\hline & Inn3 & $0.818^{* * *}$ & & & \\
\hline \multirow{4}{*}{ Proactiveness } & & $1.0^{* * *}$ & & & \\
\hline & Pro1 & $0.702^{* * *}$ & & & \\
\hline & Pro2 & $0.871^{* * *}$ & & & \\
\hline & Pro3 & $0.792^{* * *}$ & & & \\
\hline \multirow{4}{*}{$\begin{array}{l}\text { Competitive } \\
\text { aggressiveness }\end{array}$} & & $1.0^{* * *}$ & & & \\
\hline & CA1 & $0.616^{* * *}$ & & & \\
\hline & CA2 & $0.362^{* * *}$ & & & \\
\hline & CA3 & $0.501^{* * *}$ & & & \\
\hline
\end{tabular}




\subsection{Structural Model Results and Hypothesis Testing}

The SEM results for the main hypothesis between FEO and EOHEI and the moderating effect of faculty characteristics are summarized in Table 6 with the goodness-of-fit indices (GOF). GOF indicates that the hypothesized model fits the data well, and all GOF indicators are above the recommended values (Bagozzi and Yi 2012).

Table 6. Results of structural equation model BASIC Model (direct relationship between FEO and EOHEI).

\begin{tabular}{|c|c|c|c|c|c|c|}
\hline \multirow[t]{2}{*}{ Construct } & \multirow{2}{*}{$\begin{array}{r}\text { Variables } \\
\text { FEO } \rightarrow \text { EOHEI }\end{array}$} & \multirow{2}{*}{$\begin{array}{c}\text { Regression Weights } \\
0.348\end{array}$} & \multirow{2}{*}{$\begin{array}{c}\text { Standardized Weights } \\
0.381^{* * *}\end{array}$} & \multicolumn{3}{|c|}{ Goodness-of-Fit Indicators } \\
\hline & & & & GFI & 0.986 & $>0.9$ \\
\hline & Innovativeness $\rightarrow$ FEO & 1.000 & $1.115^{* * *}$ & AGFI & 0.953 & $>0.9$ \\
\hline & Risk-taking $\rightarrow$ FEO & 0.269 & $0.301^{* * *}$ & CFI & 0.994 & $>0.9$ \\
\hline & Proactivity $\rightarrow$ FEO & 0.558 & $0.561^{* * *}$ & NFI & 0.983 & $>0.9$ \\
\hline & EOHEI & & & RMSEA & 0.045 & $<0.07$ \\
\hline & $\begin{array}{c}\text { Competitive } \\
\text { aggressiveness } \rightarrow \text { EOHEI }\end{array}$ & 0.785 & $0.590^{* * *}$ & & & \\
\hline & Proactiveness $\rightarrow$ EOHEI & 1.289 & $0.869^{* * *}$ & $R^{2}$ & 0.21 & \\
\hline & Innovativeness $\rightarrow$ EOHEI & 1.518 & $0.913^{* * *}$ & & & \\
\hline & Risk-Taking $\rightarrow$ EOHEI & 1.035 & $0.667^{* * *}$ & & & \\
\hline & Autonomy $\rightarrow$ EOHEI & 1.000 & $0.573^{* * *}$ & & & \\
\hline
\end{tabular}

Note: ${ }^{* * *}$ is significant at 0.001 level.

According to the data provided in Table 4, FEO is significantly and positively influencing EOHEI with a standardized weight of 0.164 ( $p$-value $<0.001)$. FEO explains $21 \%$ of the total variation in EOHEI (R-squared). This is consistent with the findings of previous studies, which advocate the positive effect of individual intrapreneurship on the entrepreneurial activity at the organizational level (Bakar and Mahmood 2014; Clark 2004; Neessen et al. 2019). Thus, those results fully validate hypothesis 1 . As shown in Table 4, the carbon strategy construct is satisfactory (GFI, AGFI, CFI, and NFI $>0.90$ and RMSEA $<0.07)$, suggesting that the hypothesized model fits the data well. Proactivity and innovativeness have the greatest contribution to the FEO construct. Concerning EOHEI, autonomy and innovativeness are the highest contributors.

The results show also that FEO variables are significant, i.e., innovativeness, risktaking, and proactivity. The most important factor in FEO (based on standardized weights) is innovativeness (1.115), and the least one is risk-taking (0.301). Similarly, EOHEI factors are significant to EOHEI with a maximum standardized weight (importance) of 0.913 for innovativeness. Competitive aggressiveness and autonomy have the least weight in EOHEI with 0.6 weight.

\subsection{Assessment of Moderating Effect (Multi-Group Comparison)}

This section used multigroup analysis in SEM to see if the proposed relationships between FEO and EOHEI would vary across different conditions of the moderating variables (characteristics of respondents).

The primary testing method between two groups is based on checking their difference. These differences stem from structural differences in the path coefficients, not from measurement differences across groups. We tested for differences in the structural path coefficients for that analysis by using the Z-score statistics.

The results (Table 7) indicate small differences across both genders and show that the intensity of faculty entrepreneurship effect is significantly stronger among males than females ( $p$-value $<0.01$ ). Therefore, hypothesis 2 is partially supported. 
Table 7. SEM results for the relationship between FEO and EOHEI subject to gender.

\begin{tabular}{|c|c|c|c|c|c|c|c|c|}
\hline \multicolumn{3}{|c|}{ Path } & \multirow{2}{*}{$\begin{array}{c}\begin{array}{c}\text { Estimate } \\
\text { Male }\end{array} \\
0.504 * * *\end{array}$} & \multirow{2}{*}{$\begin{array}{c}\begin{array}{c}\text { Estimate } \\
\text { Female }\end{array} \\
0.004\end{array}$} & \multirow{2}{*}{$\begin{array}{c}\text { Z-Score } \\
-1.97 * *\end{array}$} & \multicolumn{2}{|c|}{$\begin{array}{l}\text { Goodness-of-Fit } \\
\text { Indicators }\end{array}$} & \multirow{2}{*}{$\begin{array}{c}\text { Acceptable } \\
\text { Standard Fit } \\
>0.90\end{array}$} \\
\hline OrgEntr & $\leftarrow$ & FacEntr & & & & GFI & 0.971 & \\
\hline F_RT & $\leftarrow$ & FacEntr & $0.351^{* * *}$ & 0.003 & -1.468 & AGFI & 0.904 & $>0.90$ \\
\hline F_Pro & $\leftarrow$ & FacEntr & $0.786 * * *$ & 0.005 & $-2.389 * *$ & CFI & 0.986 & $>0.90$ \\
\hline Org_Comp & $\leftarrow$ & OrgEntr & $0.729 * * *$ & $0.716^{* * *}$ & -0.054 & NFI & 0.967 & $>0.90$ \\
\hline Org_Pro & $\leftarrow$ & OrgEntr & $1.143^{* * *}$ & $1.399 * * *$ & 0.850 & RMSEA & 0.048 & $<0.07$ \\
\hline Org_Innov & $\leftarrow$ & OrgEntr & $1.317 * * *$ & $2.088 * * *$ & 1.698 * & & & \\
\hline Org_RT & $\leftarrow$ & OrgEntr & $1.005^{* * *}$ & $0.891^{* * *}$ & -0.496 & & & \\
\hline
\end{tabular}

Notes: ${ }^{* * *} p$-value $<0.01 ;{ }^{* *} p$-value $<0.05 ;{ }^{*} p$-value $<0.10$.

Proactivity is important to faculty entrepreneurship on the construct level for males but is insignificant for females ( $p$-value $<0.05$ ). Moreover, organizational innovativeness is important to HEI entrepreneurship for both males and females, despite the fact this dimension is significantly higher among males than females ( $p$-value $<0.1)$. Faculty risktaking is a significant factor in male faculty's entrepreneurial orientation. However, it is insignificant for females.

The examination of the moderating effect of academic qualifications indicated in Table 8 shows no significant differences between Ph.D. and Master's holders in almost all relationships studied in our model. Even though the relationship between faculty entrepreneurial orientation and the organization's entrepreneurial orientation is only significant among Ph.D. holders, the difference between Master's and Ph.D. holders is insignificant. Hence, hypothesis 3 has no support as per our results.

Table 8. SEM results for the relationship between FEO and EOHEI subject to Academic Qualification.

\begin{tabular}{ccccccccc}
\hline & Path & & $\begin{array}{c}\text { Estimate } \\
\text { Master's }\end{array}$ & $\begin{array}{c}\text { Estimate } \\
\text { Ph.D. }\end{array}$ & Z-Score & $\begin{array}{c}\text { Goodness-of-Fit } \\
\text { Indicators }\end{array}$ & $\begin{array}{c}\text { Acceptable } \\
\text { Standard Fit }\end{array}$ \\
\hline OrgEntr & $\leftarrow$ & FacEntr & 0.161 & $0.424^{* * *}$ & 1.328 & GFI & 0.965 & $>0.90$ \\
F_RT & $\leftarrow$ & FacEntr & 0.352 & $0.233^{* * *}$ & -0.427 & AGFI & 0.904 & $>0.90$ \\
F_Pro & $\leftarrow$ & FacEntr & 0.626 & $0.543^{* * *}$ & -0.174 & CFI & 0.983 & $>0.90$ \\
Org_Comp & $\leftarrow$ & OrgEntr & $1.038^{* * *}$ & $0.720^{* * *}$ & -1.135 & NFI & 0.961 & $>0.90$ \\
Org_Pro & $\leftarrow$ & OrgEntr & $1.375^{* * *}$ & $1.253^{* * *}$ & -0.416 & RMSEA & 0.049 & $<0.07$ \\
Org_Innov & $\leftarrow$ & OrgEntr & $1.446^{* * *}$ & $1.548^{* * *}$ & 0.317 & & & \\
Org_RT & $\leftarrow$ & OrgEntr & $1.152^{* * *}$ & $0.976^{* * *}$ & -0.656 & & &
\end{tabular}

The same result can be derived for the relationship between faculty risk-taking and proactivity on the one hand, with FEO on the other hand. Those relationships are significant for Ph.D. holders and are insignificant for master's holders.

As reported in Table 9, teaching experience moderately shapes the FEO effect on EOHEI. Indeed, some differences exist between faculty with more than ten years of teaching experience and the less experienced ones. Specifically, the relationship between FEO and EOHEI is only significant for the more experienced faculty ( $p$-value $<0.01$ ). In addition, proactivity is significantly important to faculty entrepreneurial orientation among the more experienced group (ten years of teaching experience or more). Still, it is not important (significant) for less experienced faculties. Overall, we can state that hypothesis 4 is partially supported. 
Table 9. SEM results for the relationship between FEO and EOHEI subject to Teaching Experience.

\begin{tabular}{|c|c|c|c|c|c|c|c|c|}
\hline \multicolumn{3}{|c|}{ Path } & \multirow{2}{*}{$\begin{array}{c}\begin{array}{c}\text { Estimate } \\
\text { Exp1 }\end{array} \\
0.009\end{array}$} & \multirow{2}{*}{$\begin{array}{c}\begin{array}{c}\text { Estimate } \\
\text { Exp2 }\end{array} \\
0.625^{* * *}\end{array}$} & \multirow{2}{*}{\begin{tabular}{|l} 
Z-Score \\
$3.353^{* * *}$
\end{tabular}} & \multicolumn{2}{|c|}{$\begin{array}{l}\text { Goodness-of-Fit } \\
\text { Indicators }\end{array}$} & \multirow{2}{*}{$\begin{array}{c}\text { Acceptable } \\
\text { Standard fit } \\
>0.90\end{array}$} \\
\hline OrgEntr & $\leftarrow$ & FacEntr & & & & GFI & 0.982 & \\
\hline F_RT & $\leftarrow$ & FacEntr & 0.015 & $0.323^{* * *}$ & 1.445 & AGFI & 0.905 & $>0.90$ \\
\hline F_Pro & $\leftarrow$ & FacEntr & 0.030 & $0.755^{* * *}$ & 1.785 * & CFI & 0.993 & $>0.90$ \\
\hline Org_Comp & $\leftarrow$ & OrgEntr & $1.280^{* * *}$ & $0.663^{* * *}$ & -1.472 & NFI & 0.981 & $>0.90$ \\
\hline Org_Pro & $\leftarrow$ & OrgEntr & $2.119^{* * *}$ & $1.032^{* * *}$ & $-2.118^{* *}$ & RMSEA & 0.044 & $<0.07$ \\
\hline Org_Innov & $\leftarrow$ & OrgEntr & $2.489^{* * *}$ & $1.214^{* * *}$ & $-2.114^{* *}$ & & & \\
\hline Org_RT & $\leftarrow$ & OrgEntr & $1.627^{* * *}$ & $0.858^{* * *}$ & $-2.077^{* *}$ & & & \\
\hline
\end{tabular}

Notes: ${ }^{* * *} p$-value $<0.01 ;{ }^{* *} p$-value $<0.05 ;{ }^{*} p$-value $<0.10$.

In regards to the effect of faculty school affiliation (business or engineering), our results reported in Table 10 suggest the existence of a significant $(p$-value $<0.05)$ relationship between FEO and EOHEI for business faculty. This relationship is not significant for engineering faculty. This provides partial support to hypothesis 5. Additionally, "faculty proactivity" and "risk-taking" are significant dimensions for business faculty entrepreneurial orientation (FEO) but not for their engineering counterparts. Yet, this difference is not significant.

Table 10. SEM results for the relationship between FEO and EOHEI subject to School Affiliation.

\begin{tabular}{|c|c|c|c|c|c|c|c|c|}
\hline & Path & & $\begin{array}{c}\text { Estimate } \\
\text { Bus }\end{array}$ & $\begin{array}{l}\text { Estimate } \\
\text { Eng }\end{array}$ & Z-Score & \multicolumn{2}{|c|}{$\begin{array}{l}\text { Goodness-of-Fit } \\
\text { Indicators }\end{array}$} & $\begin{array}{l}\text { Acceptable } \\
\text { Standard Fit }\end{array}$ \\
\hline OrgEntr & $\leftarrow$ & FacEntr & $0.484 * * *$ & 0.095 & $-2.272 * *$ & GFI & 0.970 & $>0.90$ \\
\hline F_RT & $\leftarrow$ & FacEntr & $0.317^{* * *}$ & 0.149 & -0.888 & AGFI & 0.911 & $>0.90$ \\
\hline F_Pro & $\leftarrow$ & FacEntr & $0.622 * * *$ & 0.348 & -0.694 & CFI & 0.989 & $>0.90$ \\
\hline Org_Comp & $\leftarrow$ & OrgEntr & $0.564^{* * *}$ & $2.581^{* *}$ & 1.648 & NFI & 0.968 & $>0.90$ \\
\hline Org_Pro & $\leftarrow$ & OrgEntr & $0.998^{* * *}$ & $3.662^{* *}$ & 1.618 & RMSEA & 0.042 & $<0.07$ \\
\hline Org_Innov & $\leftarrow$ & OrgEntr & $1.159^{* * *}$ & $4.936^{* *}$ & 1.675 * & & & \\
\hline Org_RT & $\leftarrow$ & OrgEntr & $0.931^{* * *}$ & $1.794^{* * *}$ & 1.284 & & & \\
\hline
\end{tabular}

Notes: ${ }^{* * *} p$-value $<0.01 ;{ }^{* *} p$-value $<0.05 ;{ }^{*} p$-value $<0.10$.

Table 11 above shows the effect of scientific productivity measured in the number of academic articles published in peer-reviewed journals. The results show that the faculty members with stronger research records (Pub2) contribute significantly more strongly to the corporate entrepreneurship undertakings of their HEIs. Research into the active faculty within their areas of specialization reflect the ability to turn ideas into action, act as team players by establishing cooperation with colleague researchers, demonstrate proactive communication skills with key stakeholders from academia and the industry, and lead research projects. However, the difference between the two groups (Engineering and Business faculty) is insignificant. Thus, hypothesis 6 is partially supported.

Table 11. SEM results for the relationship between FEO and EOHEI subject to Scientific Productivity (academic research and publications).

\begin{tabular}{|c|c|c|c|c|c|c|c|c|}
\hline \multicolumn{3}{|c|}{ Path } & \multirow{2}{*}{$\begin{array}{c}\begin{array}{c}\text { Estimate } \\
\text { Pub1 }\end{array} \\
0.254^{* * *}\end{array}$} & \multirow{2}{*}{$\begin{array}{c}\begin{array}{c}\text { Estimate } \\
\text { Pub2 }\end{array} \\
0.774^{* *}\end{array}$} & \multirow{2}{*}{$\begin{array}{c}\text { Z-Score } \\
1.349\end{array}$} & \multicolumn{2}{|c|}{$\begin{array}{l}\text { Goodness-of-Fit } \\
\text { Indicators }\end{array}$} & \multirow{2}{*}{$\begin{array}{c}\text { Acceptable } \\
\text { Standard Fit } \\
>0.90\end{array}$} \\
\hline OrgEntr & $\leftarrow$ & FacEntr & & & & GFI & 0.978 & \\
\hline F_RT & $\leftarrow$ & FacEntr & $0.312 * * *$ & 0.020 & $-1.756 *$ & AGFI & 0.927 & $>0.90$ \\
\hline F_Pro & $\leftarrow$ & FacEntr & $0.530^{* * *}$ & $0.726^{* *}$ & 0.530 & CFI & 0.996 & $>0.90$ \\
\hline Org_Comp & $\leftarrow$ & OrgEntr & $0.930^{* * *}$ & $0.638^{* * *}$ & -1.353 & NFI & 0.978 & $>0.90$ \\
\hline Org_Pro & $\leftarrow$ & OrgEntr & $1.479^{* * *}$ & $1.164^{* * *}$ & -1.326 & RMSEA & 0.028 & $<0.07$ \\
\hline Org_Innov & $\leftarrow$ & OrgEntr & $1.757 * * *$ & $1.242 * * *$ & $-1.87^{*}$ & & & \\
\hline Org_RT & $\leftarrow$ & OrgEntr & $1.460 * * *$ & $0.536^{* * *}$ & $-4.715^{* * *}$ & & & \\
\hline
\end{tabular}


Table 12 above indicates the findings pertaining to hypothesis 7 , highlighting the potential moderating effect of an individual's industrial experience on the relationship between faculty entrepreneurial orientation (FEO) and Entrepreneurial Orientation of higher education institutions (EOHEI). Overall, there is little support for hypothesis 7 as the positive relationship between FEO and EOHEI is only significant among the more experienced faculty. However, no comparison could be established with the less professionally experienced faculty as the information drawn from Table 10 shows the insignificance of the difference between the two groups.

Table 12. SEM results for the relationship between FEO and EOHEI subject to Industrial Experience.

\begin{tabular}{|c|c|c|c|c|c|c|c|c|}
\hline \multirow[b]{2}{*}{ OrgEntr } & \multirow{2}{*}{$\begin{array}{l}\text { Path } \\
\leftarrow\end{array}$} & \multirow[b]{2}{*}{ FacEntr } & \multirow{2}{*}{$\begin{array}{c}\begin{array}{c}\text { Estimate } \\
\text { Ind_Exp1 }\end{array} \\
0.179\end{array}$} & \multirow{2}{*}{$\begin{array}{c}\begin{array}{c}\text { Estimate } \\
\text { Ind_Exp2 }\end{array} \\
0.437^{* * *}\end{array}$} & \multirow{2}{*}{$\begin{array}{c}\text { Z-Score } \\
1.420\end{array}$} & \multicolumn{2}{|c|}{$\begin{array}{l}\text { Goodness-of-Fit } \\
\text { Indicators }\end{array}$} & \multirow{2}{*}{$\begin{array}{c}\text { Acceptable } \\
\text { Standard fit } \\
\quad>0.90\end{array}$} \\
\hline & & & & & & GFI & 0.987 & \\
\hline F_RT & $\leftarrow$ & FacEntr & 0.302 * & $0.265^{* * *}$ & -0.207 & AGFI & 0.922 & $>0.90$ \\
\hline F_Pro & $\leftarrow$ & FacEntr & 0.380 * & $0.650^{* * *}$ & 1.085 & CFI & 0.996 & $>0.90$ \\
\hline Org_Comp & $\leftarrow$ & OrgEntr & $1.601 * * *$ & $0.569 * * *$ & $-2.25 * *$ & NFI & 0.986 & $>0.90$ \\
\hline Org_Pro & $\leftarrow$ & OrgEntr & $2.135 * * *$ & $1.073 * * *$ & $-2.061 * *$ & RMSEA & 0.033 & $<0.07$ \\
\hline Org_Innov & $\leftarrow$ & OrgEntr & $2.868 * * *$ & $1.231 * * *$ & $-2.368 * *$ & & & \\
\hline Org_RT & $\leftarrow$ & OrgEntr & $1.553 * * *$ & $0.869 * * *$ & $-2.098 * *$ & & & \\
\hline
\end{tabular}

Notes: ${ }^{* * *} p$-value $<0.01 ;{ }^{* *} p$-value $<0.05 ;{ }^{*} p$-value $<0.10$.

The results also show that both groups of faculty members (i.e., low versus high industry experience) think that organizational competitive aggressiveness, organizational proactivity, organizational innovativeness, and organizational risk-taking are important to the organization's entrepreneurial orientation. Nonetheless, faculties with lower industrial experience score significantly higher in regards to organizational competitive aggressiveness, organizational proactivity, organizational innovativeness, and organizational risk-taking $(p$-value $<0.05)$.

Finally, the moderating effect of professional certification measured in terms of the number of professional certificates a faculty member holds was examined. The results reported in Table 13 show no significant differences between faculties with less or more professional certificates regarding the central relationship between FEO and EOHEI. Thus, hypothesis 8 is not supported.

Table 13. SEM results for the relationship between FEO and EOHEI subject to Professional Certification.

\begin{tabular}{|c|c|c|c|c|c|c|c|c|}
\hline \multicolumn{3}{|c|}{ Path } & \multirow{2}{*}{$\begin{array}{c}\begin{array}{c}\text { Estimate } \\
\text { Cert1 }\end{array} \\
0.466^{* * *}\end{array}$} & \multirow{2}{*}{$\begin{array}{c}\begin{array}{c}\text { Estimate } \\
\text { Cert2 }\end{array} \\
0.430^{* * *}\end{array}$} & \multirow{2}{*}{$\begin{array}{c}\text { Z-Score } \\
-0.176\end{array}$} & \multicolumn{2}{|c|}{$\begin{array}{l}\text { Goodness-of-Fit } \\
\text { Indicators }\end{array}$} & \multirow{2}{*}{$\begin{array}{c}\text { Acceptable } \\
\text { Standard Fit } \\
>0.90\end{array}$} \\
\hline OrgEntr & $\leftarrow$ & FacEntr & & & & GFI & 0.982 & \\
\hline F_RT & $\leftarrow$ & FacEntr & $0.670 * * *$ & $0.222 * * *$ & $-2.262 * *$ & AGFI & 0.929 & $>0.90$ \\
\hline F_Pro & $\leftarrow$ & FacEntr & $0.952^{* * *}$ & $0.590 * * *$ & -1.406 & CFI & 0.997 & $>0.90$ \\
\hline Org_Comp & $\leftarrow$ & OrgEntr & $1.147^{* * *}$ & $0.677^{* * *}$ & -1.396 & NFI & 0.981 & $>0.90$ \\
\hline Org_Pro & $\leftarrow$ & OrgEntr & $1.803^{* * *}$ & $1.126^{* * *}$ & -1.592 & RMSEA & 0.027 & $<0.07$ \\
\hline Org_Innov & $\leftarrow$ & OrgEntr & $2.414 * * *$ & $1.306 * * *$ & $-1.877^{*}$ & & & \\
\hline Org_RT & $\leftarrow$ & OrgEntr & 1.302 & 0.976 & -1.035 & & & \\
\hline
\end{tabular}

Notes: *** $p$-value $<0.01 ;{ }^{* *} p$-value $<0.05 ;{ }^{*} p$-value $<0.10$.

However, faculties with one or fewer professional certificates (i.e., Cert1) think that organizational innovativeness is more important to organizational, entrepreneurial orientation than those with more professional certificates. Similarly, the risk-taking component is significantly more important to faculty entrepreneurial orientation among faculties with fewer professional certificates (i.e., Cert1). 


\section{Discussion}

The present study explores the moderating effect of selected individual factors on the relationship that reflects the positive influence of faculty entrepreneurial behaviour on the entrepreneurial orientation of higher education institutions in Kuwait. In a country rich in entrepreneurial culture, this is a modest and ambitious attempt to explore intrapreneurship away from the industry, particularly academic organizations.

The selected demographic and personal factors empirically demonstrated various significant effects. Male faculties with industrial experience and affiliation to business schools have a stronger intrapreneurial behaviour that influences the corporate entrepreneurship of their universities or colleges. Male faculties have demonstrated higher risk-taking behaviour than females. Their previous experiences, proactive approach could explain this and the interactions between the opportunities faculties had with the industry. On the other hand, faculties with teaching experience greater than ten years scored higher on proactivity in their entrepreneurial behavior due to their accumulated experiences.

These results can be interpreted as being consistent with the previous findings of Boon et al. (2013), who conducted a focused study on fostering intrapreneurial competencies of employees in the education sector. It highlighted the important role of organizational culture in encouraging proactivity and risk-taking as elements of intrapreneurial behaviour. These dimensions were examined based on Bagheri and Pihie (2011), who integrated a model of entrepreneurship, which views entrepreneurial learning as a process that happens through experience of facing the challenges of new ventures, and social interaction and observation followed by reflection on gained experiences to draw lessons from them. They consider entrepreneurship as both scenarios and cast enactments that require building the ability to envision the future and inspire people to accomplish that vision. As per Sinha (2021), these competencies stem from the intersection of cognitive (mental), affective (emotional), and behavioral capabilities that form the "soft-spot", which leads to individual intrapreneurial behavior.

Therefore, faculties with a higher entrepreneurial orientation can influence their peers and share their envisioned opportunities with their superiors who steer the corporate entrepreneurship of their institutions. Kumar and Parveen (2021) indicated a positive and significant effect of the environment and organizational factors on intrapreneurship. Employees reciprocate management support in positive initiatives such as participation in self-renewal activities and changing approaches for process innovation. Moreover, a study by Merta et al. (2021) indicated that intrapreneurship had a significant positive effect on the work spirit, and work spirit significantly mediated the effect of intrapreneurship on organizational performance. Although this study focused primarily on personal factors rather than personality traits or competencies, it supports the findings of Woo 2018 in relation to career adaptability, which is a contemporary competence. Employees utilize resources to cope with new work demands and diverse environments. Career adaptability was found to mediate the relationship between openness and intrapreneurship and between conscientiousness and intrapreneurship. Both personality traits are associated with risktaking and proactivity, which are core elements of the individual entrepreneurial orientation (Savickas and Porfeli 2012).

Consequently, it will be an opportunity for future research on academic institutions to include personality traits and other demographic variables in addition to gender, such as age and marital status. Age, for example, is related to maturity and could generate interesting findings in relation to risk-taking and entrepreneurial behaviour. Azoulay et al. (2018) indicated that the average age of a successful start-up founder is forty-five years old.

On the other hand, the current study focused on faculties affiliated with business and engineering schools, hoping to access a sample that can generate interesting findings through our social networks in these schools. However, it would be interesting if a similar study was conducted in a context that includes faculties affiliated with different schools such as Art and Science. 


\section{Conclusions}

This study contributes to the body of literature and research on intrapreneurship in private universities and colleges, demonstrating corporate entrepreneurship related to the international growth patterns in private education worldwide. Higher education institutions will pay more attention to fostering their corporate entrepreneurship and creating new differentiation opportunities in a competitive environment.

Henceforth, this study confirmed a positive association between the faculty entrepreneurial orientation and the entrepreneurial orientation of their institutions (EOHEI). It also sheds light on some personal factors of faculty working in private academic institutions that have empirically demonstrated a moderating effect on the relationship between FEO and EOHEI.

The results of this empirical study provide indications to recommend introducing collaborations between faculties in the school of business and faculties in other schools and offering business training courses and opportunities to do mutual projects with the industry. These recommendations will help faculties in academic institutions develop a higher level of entrepreneurial behaviour or intrapreneurship orientation in their institutions. In addition, these recommendations can be generalized on the student level as they will help elevate the entrepreneurial behaviour of non-business students.

Similarly, the results indicate that the proactivity of long-serving faculties with ten years of experience or more can benefit their institutions in turning ideas and plans into actions and concrete achievements, which successful and ambitious organizations strive to achieve.

Author Contributions: All authors Conceptualized the main idea of the article; methodology: A.B.M. and O.A.; software and data analysis: A.B.-M.; validation, A.B.-M. and S.T.; investigation, K.N. and S.T.; resources: O.A.; data curation, A.B.-M. and O.A.; writing-original draft preparation, writing-review and editing: all authors; visualization: All authors; supervision: A.B.-M. and O.A.; project administration, NA; funding acquisition, NA. All authors have read and agreed to the published version of the manuscript and contributed to this work.

Funding: This research received no external funding.

Institutional Review Board Statement: Our respective institutions do not require an ethical review for the research conducted by their staff members. Such approval would be only requested if sensitive respondents' profiles are involved in the survey (e.g., children, disabled people, etc.).

Informed Consent Statement: Informed consent was obtained from all subjects involved in the study through a cover letter attached with the questionnaire. All respondents had to view and agree prior to answering the survey questions.

Data Availability Statement: Data are available on request from the corresponding author.

Conflicts of Interest: The authors declare no conflict of interest.

Appendix A

Table A1. Measurement Scale *.

Construct
Statements Assessed by the Respondents
Faculty Entrepreneurial Orientation (FEO)
In the course of my work, I generate creative ideas
I attempt to convince people to support an innovative idea
Innovativeness
I visualize a clear plan of action when I consider ways to make a new idea happen
In the course of my work, I develop new processes, services or products
I search out new techniques, technologies and/or product ideas


Table A1. Cont.

\begin{tabular}{|c|c|}
\hline Construct & Statements Assessed by the Respondents \\
\hline Risk-taking & $\begin{array}{c}\text { I boldly move ahead with a promising new approach when others might be more cautious } \\
\text { I will be willing to move to another organization and give up some salary in exchange for the } \\
\text { chance to try out my ideas if the rewards for success were adequate } \\
\text { In the course of my work, I will take calculated risks despite the possibility of failure } \\
\text { If large interests are at stake, I regularly go for the big win even when the risks are considerably } \\
\text { high } \\
\text { I take risks in my job } \\
\text { I first act and then ask for approval, even if I know that would annoy other people }\end{array}$ \\
\hline Proactivity & $\begin{array}{l}\text { I identify long term opportunities and threats for the company } \\
\text { I am known as a successful idea seller } \\
\text { I put effort in pursuing new business opportunities }\end{array}$ \\
\hline \multicolumn{2}{|c|}{ Entrepreneurial Orientation of the Higher Education Institution (EOHEI) } \\
\hline Risk-taking & $\begin{array}{l}\text { The term 'risk taker' is considered a positive attribute for people in our organization } \\
\text { People in our organization are encouraged to take calculated risks with new ideas } \\
\text { Our organization emphasizes both exploring and experimenting new ideas }\end{array}$ \\
\hline Innovativeness & $\begin{array}{c}\text { We actively introduce improvements and innovations in our organization } \\
\text { Our organization is creative in its methods of operation } \\
\text { Our organization seeks out new ways to do things }\end{array}$ \\
\hline Proactiveness & $\begin{array}{l}\text { We always try to take the initiative in every situation (e.g., against competitors, in projects and } \\
\text { when working with others) } \\
\text { We excel at identifying opportunities } \\
\text { We initiate actions to which other organizations respond }\end{array}$ \\
\hline Competitive aggressiveness & $\begin{array}{c}\text { Our organization is intensely competitive } \\
\text { In general, our organization takes a bold or aggressive approach when competing } \\
\text { We try to undo and out-maneuver the competition as best as we can }\end{array}$ \\
\hline Autonomy & $\begin{array}{c}\text { Employees are permitted to act on their own ideas without interference } \\
\text { Employees perform jobs that allow them to make and instigate changes in the way they perform } \\
\text { their work tasks } \\
\text { Employees are given freedom and independence to decide on their own how to go about doing } \\
\text { their work } \\
\text { Employees are given freedom to communicate without interference } \\
\text { Employees are given authority and responsibility to act alone if they think it to be in the best } \\
\text { interests of the business } \\
\text { Employees have access to all vital information }\end{array}$ \\
\hline \multicolumn{2}{|r|}{ HRM Effectiveness } \\
\hline Decentralization & $\begin{array}{l}\text { I have the possibility to develop new research and/or teaching programs } \\
\text { I have a part in faculty decisions about investments in new projects } \\
\text { I monitor data on my productivity (ex. research output, administrative tasks, lecture planning) } \\
\text { I determine my work flow }\end{array}$ \\
\hline Participation & $\begin{array}{l}\text { Employees are sufficiently involved } \\
\text { I am given the possibility to participate in decisions that affect my work (ex. deciding about the } \\
\text { grade distribution in courses taught, choice of the textbook, etc.) } \\
\text { I am satisfied with my possibility to participate in decisions that affect my work }\end{array}$ \\
\hline Contacts & $\begin{array}{l}\text { I feel a part of my department } \\
\text { I feel a part of my faculty/school } \\
\text { I am adequately informed about what is going on in the faculty/school } \\
\text { I am adequately informed about changes that affect my job } \\
\text { I frequently have off-the-job contacts with my colleagues }\end{array}$ \\
\hline
\end{tabular}


Table A1. Cont.

\section{Construct}

Construct

Training and development

\section{Statements Assessed by the Respondents}

How many days per year you obtained off-the- job training activities (ex. attending workshops outside your institution)?

How many days per year you obtained on-the-job general skills training not directly related to your current job?

How many days per year you obtained on-the-job skills training directly related to your current job?

\begin{tabular}{|c|c|}
\hline Employment security & This faculty/school does enough to avoid layoffs \\
\hline Social interactions & $\begin{array}{c}\text { I frequently have off-the-job contacts with my work colleagues } \\
\text { I feel very much a part of my work group } \\
\text { I feel very much a part of my faculty/school }\end{array}$ \\
\hline Compensation & How would you rate your academic salary? \\
\hline Style of management & $\begin{array}{l}\text { Which management style fits best your manager or management team: } \\
\text { Impoverished/Management (laissez-faire management)/Country Club Management (friendly } \\
\text { atmosphere)/Middle of the Road Management (balancing work and } \\
\text { people)/Authority-Compliance (efficiency)/Team Management (trust and respect) }\end{array}$ \\
\hline Communication & $\begin{array}{l}\text { I am adequately informed about what is currently going on in the faculty } \\
\text { I am adequately informed about changes that affect my job }\end{array}$ \\
\hline Performance appraisal & $\begin{array}{c}\text { Which of the two performance appraisal styles below best fits your faculty/school: } \\
\text { Judgmental-oriented or Developmental-oriented }\end{array}$ \\
\hline
\end{tabular}

Note: * The survey questions were sourced from the following references (more details in Table 2): de Jong et al. (2015); Farrukh et al. (2017); and Hughes and Morgan (2007).

\section{References}

Adachi, Takanori, and Takanori Hisada. 2017. Gender Differences in Entrepreneurship and Intrapreneurship: An Empirical Analysis. Small Business Economics 48: 447-86. [CrossRef]

Ahmed, Umair, Waheed Ali Umrani, Umer Zaman, Sheraz Mustafa Rajput, and Tariq Aziz. 2020. Corporate Entrepreneurship and Business Performance: The Mediating Role of Employee Engagement. SAGE Open 10: 2158244020962779. [CrossRef] [PubMed]

Aldahdouh, Tahani Z., Petri Nokelainen, and Vesa Korhonen. 2020. Technology and Social Media Usage in Higher Education: The Influence of Individual Innovativeness. SAGE Open 10: 2158244019899441. [CrossRef]

Al-Momani, Talal M., Ahmed A. Al-Taani, Amjad D. Al-Nasser, and Nazem M. El-Radaideh. 2011. An Assessment of Automobile Emissions in Irbid, Northwest Jordan. Electronic Journal of Applied Statistical Analysis 4: 91-102. [CrossRef]

AlQudah, Anas, Ahmed Bani-Mustafa, Khalil Nimer, Abdullah D. Alqudah, and Mostafa E. AboElsoud. 2021. The Effects of Public Governance and National Culture on Money Laundering: A Structured Equation Modeling Approach. Journal of Public Affairs 2021: e2796. [CrossRef]

Amo, Bjorn Willy. 2010. Corporate Entrepreneurship and Intrapreneurship Related to Innovation Behaviour among Employees. International Journal of Entrepreneurial Venturing 2: 144-58. [CrossRef]

Audretsch, David B. 2014. From the Entrepreneurial University to the University for the Entrepreneurial Society. The Journal of Technology Transfer 39: 313-21. [CrossRef]

Azoulay, Pierre, Benjamin Jones, J. Daniel Kim, and Javier Miranda. 2018. The Average Age of a Successful Startup Founder Is 45. Harvard Business Review On-Line. July 11. Available online: https://hbr.org/2018/07/research-the-average-age-of-a-successfulstartup-founder-is-45 (accessed on 24 November 2021).

Bagheri, Afsaneh, and Zaidatol Akmaliah Lope Pihie. 2011. Entrepreneurial Leadership: Towards a Model for Learning and Development. Human Resource Development International 14: 447-63. [CrossRef]

Bagozzi, Richard P., and Youjae Yi. 2012. Specification, Evaluation, and Interpretation of Structural Equation Models. Journal of the Academy of Marketing Science 40: 8-34. [CrossRef]

Bakar, Muhammad Shukri, and Rosli Mahmood. 2014. Linking Transformational Leadership and Corporate Entrepreneurship to Performance in the Public Higher Education Institutions in Malaysia. Advances in Management and Applied Economics 4: 109.

Bartlett, Maurice S. 1954. A Note on the Multiplying Factors for Various $\chi^{2}$ Approximations. Journal of the Royal Statistical Society. Series B (Methodological) 16: 296-98. [CrossRef]

Bierwerth, Michael, Christian Schwens, Rodrigo Isidor, and Rüdiger Kabst. 2015. Corporate Entrepreneurship and Performance: A Meta-Analysis. Small Business Economics 45: 255-78. [CrossRef]

Boon, Jo, Marcel van der Klink, and Jose Janssen. 2013. Fostering Intrapreneurial Competencies of Employees in the Education Sector. International Journal of Training and Development 17: 210-20. [CrossRef] 
Bratianu, Constantin, Shahrazad Hadad, and Ruxandra Bejinaru. 2020. Paradigm Shift in Business Education: A Competence-Based Approach. Sustainability 12: 1348. [CrossRef]

Brooksbank, David, and Brychan Thomas. 2001. An Assessment of Higher Education Spin-off Enterprises in Wales. Industry and Higher Education 15: 415-20. [CrossRef]

Burgelman, Robert A. 1983. Corporate Entrepreneurship and Strategic Management: Insights from a Process Study. Management Science 29: 1349-64. [CrossRef]

Clark, Burton R. 2004. Delineating the Character of the Entrepreneurial University. Higher Education Policy 17: 355-70. [CrossRef]

Cochran, William Gemmell. 1977. Sampling Techniques, 3rd ed. Hoboken: Wiley.

Costello, Anna B., and Jason Osborne. 2005. Best Practices in Exploratory Factor Analysis: Four Recommendations for Getting the Most from Your Analysis. Practical Assessment, Research, and Evaluation 10: 7.

Covin, Jeffrey G., and Dennis P. Slevin. 1989. Strategic Management of Small Firms in Hostile and Benign Environments. Strategic Management Journal 10: 75-87. [CrossRef]

Cvijić, Mirjana, Jovana Tatarski, Ivana Katić, Aleksandar Vekić, and Jelena Borocki. 2019. Entrepreneurial Orientation of Public Universities in Republic of Serbia-Empirical Study. Sustainability 11: 1509. [CrossRef]

Davis, Shannon N., and Shannon K. Jacobsen. 2014. Curricular Integration as Innovation: Faculty Insights on Barriers to Institutionalizing Change. Innovative Higher Education 39: 17-31. [CrossRef]

de Jong, Jeroen P. J., Sharon K. Parker, Sander Wennekers, and Chia-Huei Wu. 2015. Entrepreneurial Behavior in Organizations: Does Job Design Matter? Entrepreneurship Theory and Practice 39: 981-95. [CrossRef]

Do, Tinh Tran Phu, and Dung Tien Luu. 2020. Origins and Consequences of Intrapreneurship with Behaviour-Based Approach among Employees in the Hospitality Industry. International Journal of Contemporary Hospitality Management 13: 3949-69. [CrossRef]

Farrukh, Muhammad, Wei Ying Chong, Shaheen Mansori, and Sara Ravan Ramzani. 2017. Intrapreneurial behaviour: The role of organizational commitment. World Journal of Entrepreneurship, Management and Sustainable Development 13: 243-56. [CrossRef]

Farrukh, Muhammad, Fanchen Meng, and Ali Raza. 2021. Believe They Can Succeed, and They Will: Intrapreneurial Behavior and Leadership. European Journal of Innovation Management. ahead-of-print. [CrossRef]

Fini, Riccardo, Kun Fu, Marius Tuft Mathisen, Einar Rasmussen, and Mike Wright. 2017. Institutional Determinants of University Spin-off Quantity and Quality: A Longitudinal, Multilevel, Cross-Country Study. Small Business Economics 48: 361-91. [CrossRef]

Gawke, Jason C., Marjan J. Gorgievski, and Arnold B. Bakker. 2017. Employee Intrapreneurship and Work Engagement: A Latent Change Score Approach. Journal of Vocational Behavior 100: 88-100. [CrossRef]

Gawke, Jason C., Marjan J. Gorgievski, and Arnold B. Bakker. 2019. Measuring Intrapreneurship at the Individual Level: Development and Validation of the Employee Intrapreneurship Scale (EIS). European Management Journal 37: 806-17. [CrossRef]

Hair, Joe F., Marko Sarstedt, Christian M. Ringle, and Jeannette A. Mena. 2012. An assessment of the use of partial least squares structural equation modeling in marketing research. Journal of the Academy of Marketing Science 40: 414-33. [CrossRef]

Hair, Joseph F., Christian M. Ringle, and Marko Sarstedt. 2013. Partial Least Squares Structural Equation Modeling: Rigorous Applications, Better Results and Higher Acceptance. Long Range Planning 46: 1-12. [CrossRef]

Hayat, Naeem. 2011. The Entrepreneurial Orientation Can Enhance the Teacher Performance in Higher Education. Revista Românească Pentru Educaţie Multidimensională 3: 85-96. [CrossRef]

Hayter, Christopher S. 2013. Harnessing University Entrepreneurship for Economic Growth: Factors of Success among University Spin-Offs. Economic Development Quarterly 27: 18-28. [CrossRef]

Hobfoll, Stevan E. 2001. The Influence of Culture, Community, and the Nested-self in the Stress Process: Advancing Conservation of Resources Theory. Applied Psychology 50: 337-421. [CrossRef]

Hoque, Abu Shams Mohammad Mahmudul, Benazir Ahmed Siddiqui, Zainudin bin Awang, and Syed Muhammad Awaluddin Tuan Baharu. 2018. Exploratory Factor Analysis of Entrepreneurial Orientation in the Context of Bangladeshi Small and Medium Enterprises (SMEs). European Journal of Physical Education and Sport Science 3: 81-94. [CrossRef]

Hornsby, Jeffrey S., Donald F. Kuratko, Daniel T. Holt, and William J. Wales. 2013. Assessing a Measurement of Organizational Preparedness for Corporate Entrepreneurship. Journal of Product Innovation Management 30: 937-55. [CrossRef]

Hughes, Mathew, and Robert E. Morgan. 2007. Deconstructing the relationship between entrepreneurial orientation and business performance at the embryonic stage of firm growth. Industrial Marketing Management 36: 651-61. [CrossRef]

Ireland, R. Duane, Donald F. Kuratko, and Jeffrey G. Covin. 2003. Antecedents, elements, and consequences of corporate entrepreneurship strategy. In Academy of Management Proceedings. Briarcliff Manor: Academy of Management, vol. 2003, pp. L1-L6.

Ireland, R. Duane, Jeffrey G. Covin, and Donald F. Kuratko. 2009. Conceptualizing Corporate Entrepreneurship Strategy. Entrepreneurship Theory and Practice 33: 19-46. [CrossRef]

Kearney, Sean. 2013. Improving engagement: The use of 'Authentic self-and peer-assessment for learning'to enhance the student learning experience. Assessment E Evaluation in Higher Education 38: 875-91.

Kim, Jeong-Nam. 2012. From Relational Quality to Communicative Actions of Publics and Stakeholders: Understanding Causality Loops between Behaviors of Organizations and Behaviors of Publics in Strategic Communication. International Journal of Strategic Communication 6: 1-6. [CrossRef]

Kraus, Sascha, Matthias Breier, Paul Jones, and Mathew Hughes. 2019. Individual Entrepreneurial Orientation and Intrapreneurship in the Public Sector. International Entrepreneurship and Management Journal 15: 1247-68. [CrossRef] 
Kreiser, Patrick M., Donald F. Kuratko, Jeffrey G. Covin, R. Duane Ireland, and Jeffrey S. Hornsby. 2021. Corporate Entrepreneurship Strategy: Extending Our Knowledge Boundaries through Configuration Theory. Small Business Economics 56: 739-58. [CrossRef]

Kumar, Sunayana, and Rakhshanda Parveen. 2021. Assessing the Factors of Employees' Intrapreneurial Behaviour: An Indian Context. World Journal of Entrepreneurship, Management and Sustainable Development 17: 804-21. [CrossRef]

Lizote, Suzete Antonieta, Jeferson Lana, and Miguel Angel Verdinelli. 2014. Intrapreneurial Behavior: A Study of Higher Education Institutions. Revista Alcance 21: 518-37. [CrossRef]

Martiarena, Aloña. 2013. What's so Entrepreneurial about Intrapreneurs? Small Business Economics 40: 27-39. [CrossRef]

Meilani, Any, and Ginta Ginting. 2018. The Variables and Dimensions of Entrepreneurial Orientation Perceived by Lecturers of Higher Education Institutions. Review of Integrative Business and Economics Research 7: 404-10.

Merta, I. Ketut, I. Wayan Gede Supartha, I. Made Artha Wibawa, and Ida Bagus Ketut Surya. 2021. Does Intrapreneurship increase work spirit and performance of village credit Institutions? Problems and Perspectives in Management 19: 107-17. [CrossRef]

Moore, Gary C., and Izak Benbasat. 1991. Development of an Instrument to Measure the Perceptions of Adopting an Information Technology Innovation. Information Systems Research 2: 192-222. [CrossRef]

Moussa, Tantawy, Amir Allam, Said Elbanna, and Ahmed Bani-Mustafa. 2020. Can Board Environmental Orientation Improve U.S. Firms' Carbon Performance? The Mediating Role of Carbon Strategy. Business Strategy and the Environment 29: 72-86. [CrossRef]

Mustafa, Michael, Fiona Gavin, and Mathew Hughes. 2018. Contextual Determinants of Employee Entrepreneurial Behavior in Support of Corporate Entrepreneurship: A Systematic Review and Research Agenda. Journal of Enterprising Culture 26: 285-326. [CrossRef]

Neessen, Petra C. M., Marjolein C. J. Caniëls, Bart Vos, and Jeroen P. de Jong. 2019. The Intrapreneurial Employee: Toward an Integrated Model of Intrapreneurship and Research Agenda. International Entrepreneurship and Management Journal 15: 545-71. [CrossRef]

Nielsen, Jelena Erić, Verica Babić, Vesna Stojanović-Aleksić, and Jelena Nikolić. 2019. Driving Forces of Employees' Entrepreneurial Intentions-Leadership Style and Organizational Structure. Management: Journal of Sustainable Business and Management Solutions in Emerging Economies 24: 59. [CrossRef]

Pallant, Julie. 2013. SPSS Survival Manual. London: McGraw-Hill Education.

Park, Soo Hyun, Jeong-Nam Kim, and Arunima Krishna. 2014. Bottom-up Building of an Innovative Organization: Motivating Employee Intrapreneurship and Scouting and Their Strategic Value. Management Communication Quarterly 28: 531-60. [CrossRef]

Rauch, Andreas, Johan Wiklund, George T. Lumpkin, and Michael Frese. 2009. Entrepreneurial Orientation and Business Performance: An Assessment of Past Research and Suggestions for the Future. Entrepreneurship Theory and Practice 33: 761-87. [CrossRef]

Riggs, Valerie. 2019. Examining the Relationship between HBCU Faculty Online Education, Innovativeness and Attitudes toward Computers. Baltimore: Morgan State University.

Savickas, Mark L., and Erik J. Porfeli. 2012. Career Adapt-Abilities Scale: Construction, Reliability, and Measurement Equivalence across 13 Countries. Journal of Vocational Behavior 80: 661-73. [CrossRef]

Serinkan, Celalettin, Keziban Kaymakçi, Gülşah Arat, and Cennet Avcik. 2013. An Empirical Study on Intrapreneurship: In A Service Sector in Turkey. Procedia-Social and Behavioral Sciences 89: 715-19. [CrossRef]

Shane, Scott Andrew. 2004. Academic Entrepreneurship: University Spinoffs and Wealth Creation. Cheltenham: Edward Elgar Publishing.

Sinha, Jagdish N. 2021. Book Review: Suvobrata Sarkar, Let There Be Light: Engineering, Entrepreneurship and Electricity in Colonial Bengal, 1880-1945. Studies in People's History 8: 154-56. [CrossRef]

ul Haq, Muhammad Anwar, Muhammad Usman, and Shaista Khalid. 2018. Employee Empowerment, Trust, and Innovative Behavior: Testing a Path Model. Journal on Innovation and Sustainability RISUS 9: 3-11. [CrossRef]

Usman, Muhammad, Moazzam Ali, Chidebere Ogbonnaya, and Mayowa T. Babalola. 2021. Fueling the Intrapreneurial Spirit: A Closer Look at How Spiritual Leadership Motivates Employee Intrapreneurial Behaviors. Tourism Management 83: 104227. [CrossRef]

Valka, Kristine, Catarina Roseira, and Pedro Campos. 2020. Determinants of University Employee Intrapreneurial Behavior: The Case of Latvian Universities. Industry and Higher Education 34: 190-202. [CrossRef]

Wahyudi, Indra, Arif Imam Suroso, Bustanul Arifin, Rizal Syarief, and Meika Syahbana Rusli. 2021. Multidimensional Aspect of Corporate Entrepreneurship in Family Business and SMEs: A Systematic Literature Review. Economies 9: 156. [CrossRef]

Wolcott, Robert C., and Michael J. Lippitz. 2007. The Four Models of Corporate Entrepreneurship. MIT Sloan Management Review 49: 75.

Woo, Hyung Rok. 2018. Personality Traits and Intrapreneurship: The Mediating Effect of Career Adaptability. Career Development International 23: 145-62. [CrossRef]

Yang, Yi, Vadake K. Narayanan, and Shaker Zahra. 2009. Developing the Selection and Valuation Capabilities through Learning: The Case of Corporate Venture Capital. Journal of Business Venturing 24: 261-73. [CrossRef] 